\title{
Economic Thresholds in Soybean-Integrated Pest Management: Old Concepts, Current Adoption, and Adequacy
}

\author{
AF Bueno ${ }^{1}$, SV Paula-Moraes ${ }^{2}$, DL Gazzoni ${ }^{1}$, AF Pomari ${ }^{3}$ \\ ${ }^{1}$ Embrapa Soja, Londrina, PR, Brasil \\ ${ }^{2}$ Embrapa Cerrados, Brasília, DF, Brasil \\ ${ }^{3}$ Univ de São Paulo, Fac de Filosofia, Ciências e Letras, Ribeirão Preto, SP, Brasil
}

\section{Keywords}

Economic injury level, insecticide, pest control, sustainable pest management

\section{Correspondence \\ AF Bueno, Embrapa Soja, Rod. Carlos João Strass - Distrito de Warta, Caixa Postal 231, 86001-970 Londrina, Paraná, Brasil; adeney.bueno@embrapa.br \\ Invited paper \\ Received 27 July 2013 and accepted 19 August 2013 \\ Published online: 13 September 2013 \\ (C) Sociedade Entomológica do Brasil 2013}

\begin{abstract}
Increasing global demands for food underline the need for higher crop yields. The relatively low costs of the most commonly used insecticides in combination with increasing soybean market prices led growers and technical advisors to debate the adequacy of recommended economic thresholds (ETs). The adoption of ETs and pest sampling has diminished in Brazil, leading to excessive pesticide use on soybean. The reduced efficacy of natural biological control, faster pest resurgence, and environment contamination are among the side-effects of pesticide abuse. To address these problems and maximize agricultural production, pest control programs must be guided by a proper integrated pest management (IPM) approach, including the ET concept. Therefore, the most appropriate time to initiate insecticide spraying in soybean is indicated by the available ETs which are supported by experiments over the last 40 years in different edapho-climatic conditions and regions with distinct soybean cultivars. Published scientific data indicate that preventive insecticide use is an expensive and harmful use of chemicals that increases the negative impact of pesticides in agroecosystems. However, the established ETs are for a limited number of species (key pests), and they only address the use of chemicals. There is a lack of information regarding secondary pests and other control strategies in addition to insecticides. It is clear then that much progress is still needed to improve ETs for pest management decisions. Nevertheless, using the current ETs provides a basis for reducing the use of chemicals in agriculture without reducing yields and overall production, thereby improving sustainability.
\end{abstract}

\section{Introduction}

No concept has influenced pest control technology in modern agricultural history more than integrated pest management (IPM) (Pedigo \& Higley 1996). The first published reference to "management" in the context of pests, in which scientists argued for a change in strategies for dealing with pests in favor of sustainability and environmental quality over the "identify and spray strategy" was made by Geier \& Clark (1961). This proposed strategy was initially known as pest management and was later called IPM (Pedigo 1995). In this context, the history of IPM on soybean is linked to these changes in the pest control concept that took place in the 1960s, at the same time that the world was alerted to the danger of abusive pesticide use by the publication of "Silent Spring" (Carson 1962). The overuse of pesticides and its consequences, as illustrated in "Silent Spring", led to the development of several governmental policies to mitigate the side-effects of such chemicals, and a major component of this change was the implementation of IPM programs in different countries (Kogan 1998, Panizzi 2013).

The IPM concept is based on the premise that cultivated plants can tolerate certain levels of injury without economically significant yield reductions (Higley \& Peterson 1996), and in 
some cases, small amounts of vegetal tissue injury can actually increase yields (Fig 1) (Paula et al 1998, Peterson \& Higley 2001, Picanço et al 2004). Therefore, not all herbivorous insects will become pests and require control (Higley \& Pedigo 1996, Pedigo \& Rice 2009). In this context, Stern et al (1959) defined the lowest pest population that is able to cause economic damage to plants as the economic injury level (EIL). However, to avoid reaching the EIL and consequent losses to productivity, several factors should be taken into consideration, such as the time needed for the control measures to become effective against these pests, and climate factors that can delay the implementation of a control measure, among others. Therefore, a decision regarding whether to control a pest population should always be made before the EIL is reached. The appropriate time to initiate the control measure to prevent the pest population from reaching the EIL is termed the economic threshold (ET) (Pedigo et al 1986). Thus, the ET represents the moment when the pest population must be controlled to avoid reaching the EIL (Stern et al 1959). That is the reason for the ET value being typically set below the EIL, which may be dynamic, but most of the existing ETs are static.

The ET has practical applications in the agro ecosystem (Paula-Moraes et al 2013) and is based on time (Pedigo \& Rice 2009). When information is available, the ET may consider the pest population growth rate. Therefore, insecticides should not be preventively applied to crops, such as soybean, and insecticide use is only justifiable when the pest population is equal to or greater than the ET or is expected to surpass this level within hours or days.

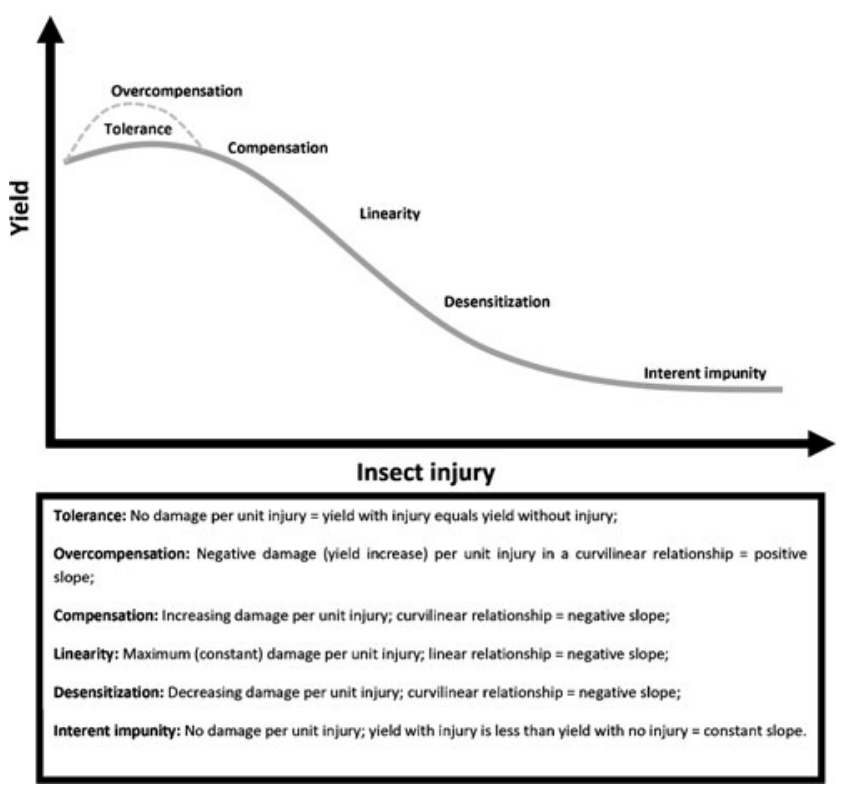

Fig 1 Illustration of the relationship between yield and insect injury (damage curve) (Adapted from Peterson \& Higley 2001).
Present ETs for Soybean-IPM

The soybean economic pest threshold levels were determined in the 1970 for the most important pests in both temperate and tropical areas (Fig 2). For the majority of soybean pests in Brazil, it is now possible to use control measures based on scientific data, which contributes to appropriate pesticide use. However, there are still some more recent soybean pests, such as mites, whiteflies, and even some pod-feeder caterpillars for which ETs must be established (Bueno et al 2012).

The recommended ETs for lepidopteran larvae which feed exclusively on the leaf lamina of soybean plants; usually Anticarsia gemmatalis Hübner and Chrysodeixis includes (Walker); differ slightly by location. In the USA, which is the largest soybean producer, the ET is $35 \%$ defoliation at the vegetative stage and $20 \%$ at the reproductive stage (Andrews et al 2009). In Brazil, the second largest soybean producer, pest-control measures are triggered either when 20 large $(\geq 1.5 \mathrm{~cm})$ lepidopteran larvae are counted per beat cloth (1-metersoybean line) or when 30\% defoliation (in the vegetative stage) or $15 \%$ defoliation (in the reproductive state) is recorded (Fig 2) (Bueno et al 2011a, Batistela et al 2012).

In the same manner, the recommended ETs for stinkbugs differ slightly between these two countries (the USA and Brazil). In the USA, the ET for seed-sucker stinkbugs is three bugs larger than $0.6 \mathrm{~cm} /$ row $m$ if a beat cloth is used as the sampling method. Alternatively, if a sweep net is used for sampling, the ET is nine bugs per 25 sweeps (Andrews et al 2009). In Brazil, only the beat cloth is recommended as a sample method for seed-sucker stinkbug control, and the ETs are variable depending on the production system (Fig 2). For grain production, the ET is two bugs larger than $0.5 \mathrm{~cm} /$ row $\mathrm{m}$. In the case of seed production, the ET is only one bug larger than $0.5 \mathrm{~cm}$ (Bueno et al 2012).

The term "stinkbug" usually refers to a complex of phytophagous species that damage soybeans by piercing the pod hulls and sucking juices from developing seeds. This type of feeding habits can result in unfilled pods, severely shrunken seeds, or discolored seeds around the puncture sites. Punctured seeds can lead to lower grades and lower germination. All stinkbugs feed on the developing stages of soybeans, but the greatest yield impact is caused by the third, fourth, and fifth instars and adults (Andrews et al 2009). These pests are gaining importance in Brazil and some other countries; thus, growers in fear of some degree of yield losses question the viability of the recommended ET. Questions have been raised, particularly with respect to early soybean cultivars with indeterminate growth habits, which produce pods for a longer period during the plant cycle. 


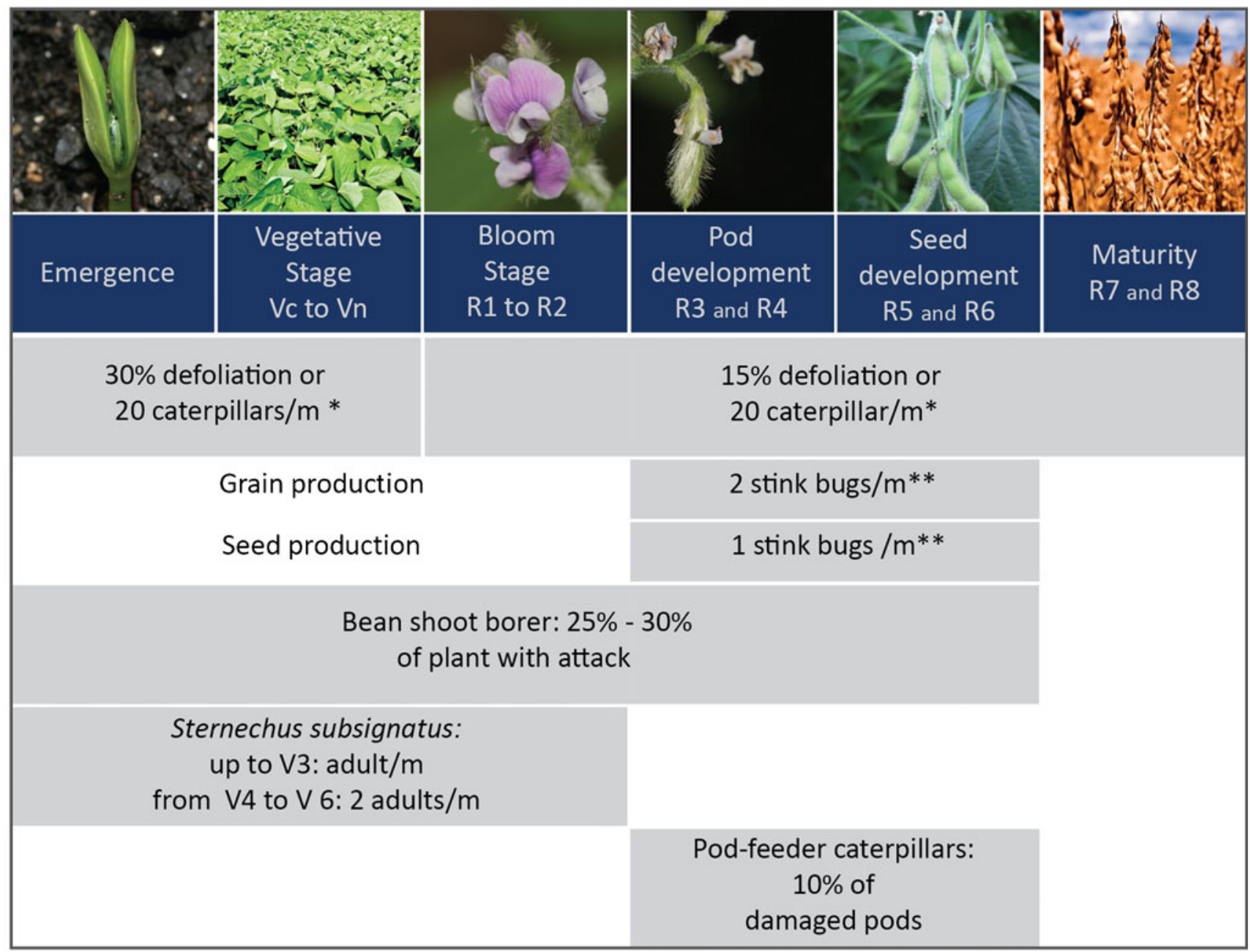

' Bigger than $1.5 \mathrm{~cm}$ and considering the drop cloth used in $1 \mathrm{~m}$.

** Bigger than $0.5 \mathrm{~cm}$ and considering the drop cloth used in $1 \mathrm{~m}$.

Fig 2 ETs for the most important soybean pests in Brazil.

\section{Changes in soybean scenarios and related doubts about ET accuracy}

As mentioned previously, soybean pest EILs and ETs were developed in the 1970s. However, soybean cultivars and their production systems have undergone dramatic changes in recent years. In this context, the current cultivars have improved yields and different growth habits (determinate and indeterminate), and they usually have shorter maturity periods, among other traits (Batistela et al 2012).

During the 1970s, the Brazilian soybean average yield was $1,500 \mathrm{~kg} / \mathrm{ha}$, and the current average is higher than $3,000 \mathrm{~kg} / \mathrm{ha}$ (CONAB 2013). This increased plant production sometimes leads growers to believe that a standardized amount of injury (the same percentage of defoliation, for example) can cause a more valuable yield reduction (in percent) than in the past, so they demand an ET reduction. However, this judgment is not factual because the immediate plant response to injury is not linear. It is crucial to consider that a plant response to injury includes tolerance and sometimes overcompensation, making the relationship between the intensity of injury and yield loss (Fig 1) a curve and not a straight line (Peterson \& Higley 2001, Pedigo \& Rice 2009). In this context, it is important to emphasize that the soybean plant tolerates some injury levels (pest feeding) without any decrease in yield and, therefore, no control is needed (Haile et al 1998).

In addition, scientists have suggested that new soybean cultivars with a lower leaf area index are more sensitive to defoliation, arguing that the leaf area index is crucial to soybean yield. However, it is important to emphasize that total dry weight (which has been recorded to be higher in some newer soybean cultivars) is more closely related to soybean yield than the leaf area index (Kumudini et al 2001). Moreover, during certain times in the soybean development cycle of newer cultivars, the leaf area index maybe smaller; however, this is not true over the entire course of development. Some older soybean cultivars with greater leaf area 
indexes during the early development stages are more vulnerable to leaf self-shading, which can trigger earlier leaf senescence relative to the newer cultivars. Consequently, when the plant needs leaves the most, as in the R5 growth stage, newer cultivars might have a higher leaf area index compared with older cultivars because of their ability to retain leaves for longer periods (Kumudini et al 2001). In addition to the leaf area index, the light interception effect should also be taken into consideration (Haile et al 1998). Thus, assuming that a newer cultivar will be more sensitive to defoliation involves some biases and cannot be assumed as a fact. Soybean sensitivity to defoliation usually peaks at the early $\mathrm{R} 5$ growth stage and decreases linearly down to less than $10 \%$ of the relative yield loss at the late $\mathrm{R} 6$ growth stage (Board et al 2010).

Another doubt regarding the ET accuracy in Soybean-IPM is related to how the EIL is calculated and how this calculation might affect the ET. Pedigo et al (1986) proposed a general model for EIL as follows: EIL=C/VDIK, where EIL=EIL in injury equivalents per production unit (e.g., insects per hectare), $C=$ management cost per production unit (in dollars per hectare), $V=$ market value per unit of production (in dollars per kilogram), $D=$ damage per unit injury (in kilograms reduction per hectare per injury), I=injury per pest equivalent (in injury per insect), and $K=$ proportional reduction in injury with management (Higley \& Pedigo 1996). Therefore, considering that insecticides are generally less expensive (thus, $C$ would be lower in the EIL equation) and soybean is more valuable (thus, $V$ would be higher in the EIL equation) in comparison to past years, the EIL should be lowered and, consequently, the ET should be lowered to reflect these changes. However, the EIL calculation considers the linear part of the curve that represents the relationship between insect injury and yield loss. If the ET is set much lower than the pest density at the EIL, then there is a risk of establishing a pest level that falls into the tolerance or overcompensation part of the curve (Fig 1) (Peterson \& Higley 2001). This ET reduction can never be performed if the ET falls into the tolerance or overcompensation phases. Thus, before taking the need for an ET reduction for granted, it is important to determine if the insect damage does not fall into the tolerance or the overcompensation phases of the damage curve.

Earlier results reported soybean defoliation levels of up to $50 \%$ (Pickle \& Caviness 1984) or even $100 \%$ at the $R^{2}$ stage (Gazzoni \& Moscardi 1998) without yield reduction. These results are most likely explained by the soybean tendency to produce an excessive leaf area. This characteristic, which is also present in other plant species, allows plants to achieve maximum solar radiation interception for photosynthesis, even after some defoliation (Brougham 1956, 1958, Davidson \& Donald 1958, Watson 1958, Murata 1961, Stern \& Donald 1962). This compensation occurs because a small loss in leaf area can be compensated by greater light penetration to the lower leaves, which were previously shaded, leading to an increased total production of photosynthesized products by the plant and causing them to produce a grain yield similar to that of plants without defoliation or even inducing a slightly higher yield than that of non-defoliated individuals (Turnipseed 1972).

Even though many of these studies were carried out in the 1970 or 1980 , several more recently published papers have shown these levels are still reliable (Costa et al 2003, Reichert \& Costa 2003, Batistela et al 2012). Among the recent studies, Batistela et al (2012) showed that even the newer soybean cultivars, regardless of their growth habit (determinate or indeterminate), can tolerate defoliation levels supported by the ET without a significant reduction in yield (Fig 3).

Similarly, historic stinkbug ETs can be safely adopted. Soybean plants tolerate two stinkbugs larger than $0.5 \mathrm{~cm} /$ row $\mathrm{m}$ without any yield reduction or quality loss in response to pest feeding. When the current stinkbug ET (2 stinkbugs $\geq 0.5 \mathrm{~cm} / \mathrm{m}$ ) was compared with a reduced ET $(1 / 4 \mathrm{ET}=0.5$ stinkbugs $\geq 0.5 \mathrm{~cm} / \mathrm{m})$ in a soybean cultivar of indeterminate growth habit, the results indicated that a

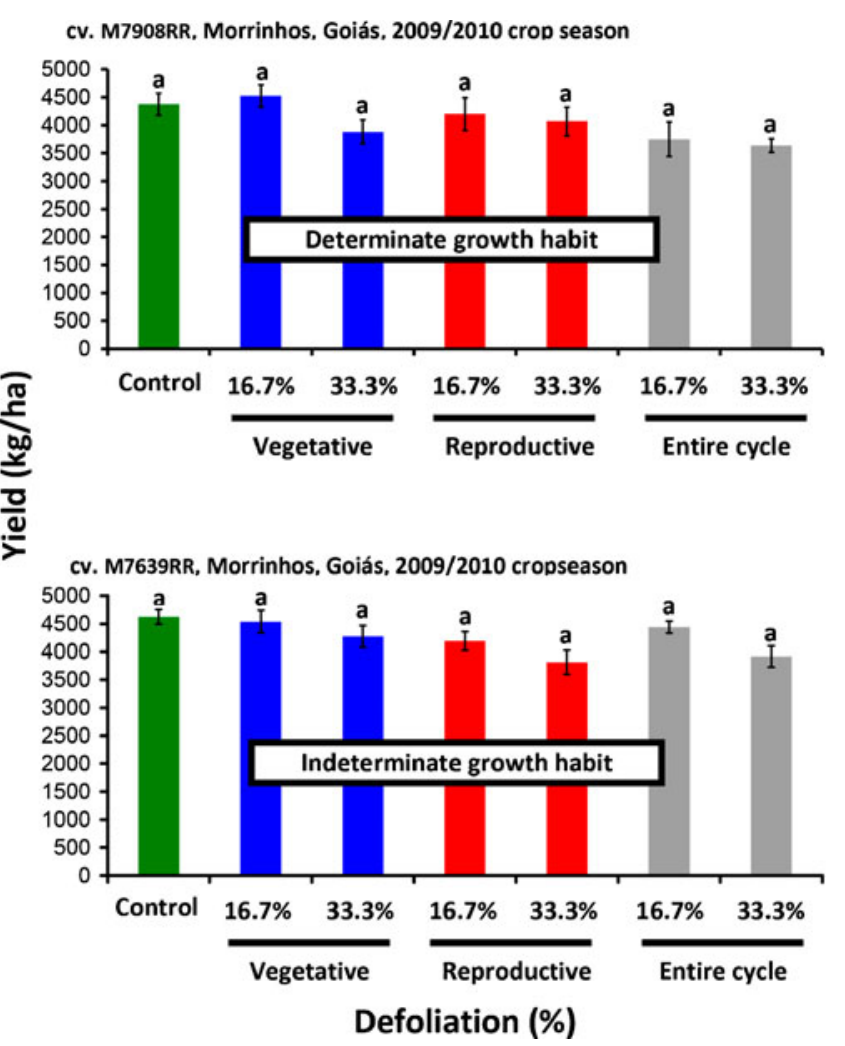

Fig 3 Mean soybean production ( \pm SE) with seeds at $13 \%$ moisture after different defoliation intensities (in percent) at different developmental stages for two soybean cultivars (M7908RR and M7637RR) grown in the municipality of Morrinhos, state of Goiás, Central Brazil, during the $2009 / 2010$ crop season. Means followed by the same letter are not significantly different from one another according to Tukey's test at a 5\% probability for each experiment (adapted from Batistela et al 2012). 
smaller population of stinkbugs (0.50 stinkbugs $\geq 0.5 \mathrm{~cm}$ / $\mathrm{m})$ led to a similar yield when compared with other treatments (Table 1). By contrast, less stinkbugs required a higher number of insecticide applications and higher economic and environmental costs for a total of six insecticide applications, whereas the treatment under the recommended ET ( 2 stinkbugs $\geq 0.5 \mathrm{~cm} / \mathrm{m}$ ) required only two insecticide applications (Fig 2).

In Brazil, stinkbug populations have increased significantly in soybean, and this is especially true for Euschistus heros (Fabricius; Hemiptera: Pentatomidae) (Panizzi et al 2000) for the following reasons: (1) resistant stinkbug populations have been selected by the most used pesticides; (2) there is a low number of insecticides with different mechanisms of action; (3) there are deficiencies in insecticide spraying technology; and (4) there exists an ecological imbalance caused by the excessive and disordered use of broad spectrum insecticides, mainly during the early developmental stages of the culture (Bueno et al 2011a, Corrêa-Ferreira et al 2010). Therefore, the increased use of insecticides in soybean fields caused by the adoption of a reduced ET will only aggravate these problems and will not result in yield increases. Thus, as previously stated for defoliators, the overuse of insecticides brings more harm than benefits, especially considering that there is no scientific support for the idea that a lower ET correlates to higher yields.

Arguments have also been asserted that, outside of yield reduction, soybean seed quality is threatened by stinkbug populations at the present ET recommendation. However, stinkbug damage, evaluated by the tetrazolium test, was not significantly different between plots with ET of 0.5 bugs $/ \mathrm{m}$ and those with ET of 2 bugs/m (Table 1). The control plots

Table 1 Soybean yield and seed quality following the adoption of different management practices for the control of stinkbugs.

\begin{tabular}{|c|c|c|c|}
\hline & Treatment & $\begin{array}{l}\text { Production } \\
\text { (kg/ha) }\end{array}$ & $\begin{array}{l}\text { Tetrazolium } \\
\text { test (\%) } \\
\text { Stinkbug injury } \\
\text { (scale } 6 \text { to } 8 \text { ) }\end{array}$ \\
\hline 1 & $\begin{array}{l}\text { Economic threshold (ET) } \\
\text { for stinkbugs }\end{array}$ & $3,812.5 \pm 96.5 a^{a}$ & $4.5 \pm 2.6 b^{a}$ \\
\hline 2 & $1 / 4$ of the ET for stinkbugs & $3,992.9 \pm 116.5$ a & $1.0 \pm 0.4 \mathrm{~b}$ \\
\hline 3 & $\begin{array}{l}\text { Insecticide mixed with } \\
\text { herbicides and fungicides }\end{array}$ & $3,678.9 \pm 76.6 \mathrm{a}$ & $4.8 \pm 2.3 \mathrm{~b}$ \\
\hline \multirow[t]{2}{*}{4} & Control & $3,267.2 \pm 39.9 b$ & $13.7 \pm 2.2 \mathrm{a}$ \\
\hline & CV (\%) & 4.78 & 30.00 \\
\hline
\end{tabular}

Municipality of Arapongas, State PF Paraná, South Brazil, 2010/2011 season.

${ }^{a}$ Means followed by the same letter in the column are not significantly different from one another according to Tukey's test $(P>0.05)$.

${ }^{b}$ Original results followed by the statistics performed on data transformed by $\sqrt{X}$ (these data indicated the percentage of seeds with dead embryos resulting from stinkbug injury). resulted in $13.7 \%$ of grains with dead embryos (Table 1), but the stinkbug population was over 6 stinkbugs/m from $\mathrm{R} 5$ to maturation (Fig 4 ). It is worth mentioning that a seed damage rate of $6 \%$ is legally accepted for certified seed production. Therefore, in accounting for either yield or seed quality, there is no support for reducing the currently recommended stinkbug ETs.

Both the stinkbug and defoliation results discussed here refute the hypotheses that a standardized amount of injury (the same percentage of defoliation or stinkbug feeding, for example) is now able to trigger a higher (or more valuable) yield reduction than it had in the past. Instead, the results indicate that both the defoliation and stinkbug ET appears to lie within the tolerance phase of the damage curve (Fig 1) and, therefore, no reduction is necessary for either ET values.

How safe is it to simultaneously adopt all ETs, which means adopting the whole soybean -IPM program?

Guaranteed positive results for adopting ETs without any risk to the soybean yield are a pre-requisite to the massive adoption of this tactic and of larger soybean-IPM programs as well. Bueno et al (2011a) observed no differences between the recommended IPM and the grower management plots (Table 2). In this context, it should also be reemphasized that a higher use of insecticides, in addition to not providing better control and having higher costs, can be harmful to humans and to the environment, can aggravate pest resurgence, cause secondary pest outbreaks and increase pest resistance to primary insecticides (Meissle et al 2010, Tang et al 2010).

\section{The future for ETs in soybean-IPM}

Transgenic plants have become a new platform for pest control around the world in several commodities such as cotton and corn. In Brazil, it is expected there will be a massive adoption of the first soybean $B t$ plant expressing the Cry 1Ac toxin during the 2013/2014 crop season and flowing years. Given this circumstance, questions have been raised about the future of IPM in soybean.

First, it is critical to understand that $B t$ toxins do not represent a solution for all pest problems because their use represents a specific control method, and different toxins target different pests. Therefore, $B t$ technology does not invalidate the need to scout and monitor pests in the field. The IPM approach will continue to be useful in this new transgenic scenario. One example is the presence of the Cry 1Ac toxin in cotton: it has insecticidal effects on Helicoverpa spp., but the toxin only controls the first larval stage sand is not completely effective against this genus. Thus, it might be necessary to redesign the EIL and ET for this pest because some insecticidal applications may be 
Fig 4 Mean population ( \pm SE) of stinkbugs along with the soybean crop developmental stages after different treatments (indicated by the arrows) for pest control. Municipality of Arapongas, sate of Paraná, South Brazil, 2010/ 2011 crop season.

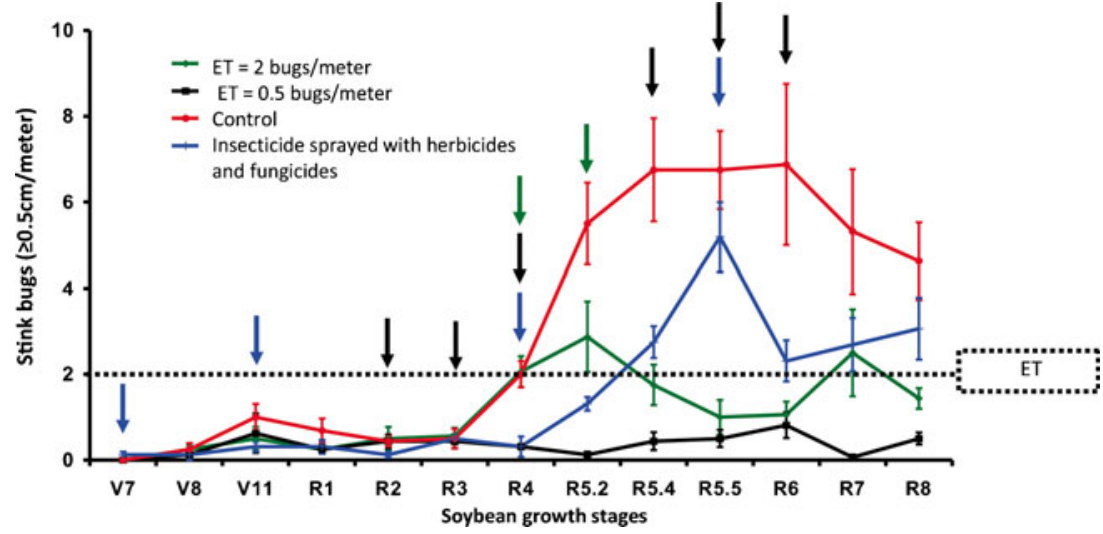

necessary, especially at the end of the crop cycle, to control the old larvae that remain in the crop (Naranjo et al 2008). Additionally, appropriate adoption of these transgenic crops demands the establishment of refuge areas to avoid or at least delay the evolution of pest resistance to $B t$ technology. The refuge area plays a role in supplying insects that have not been selected for toxin resistance. It is possible to adopt management measures in a refuge area based on an estimate of the pest population density. However, the refuge area plays a dual role by producing both soybeans and insects, and it is important to question whether we should be as rigorous in the refuge area for caterpillars as we are in non- $B t$ areas.

Moreover, Bt technology could contribute to changes in the key pest complexes of these crops. These changes could eliminate the inter specific competition or density population increase of other pest groups that are not targeted by $B t$ toxins. Examples include sucking insects such as trips, aphids and other bugs, which are not targeted by Bt technology; furthermore, considering decreased insecticidal applications, former secondary pests could change its status in the crop and may require different management practices.

Another factor is related to the development of EIL for a unique pest species. Considering that growers commonly face multiple pests under normal field conditions (Hammond 1996), one possible refinement to the EIL concept would be to develop EILs and, consequently, ETs for multiple pest species, given that these pests have the same feeding niche and produce similar plant injuries. This improvement was highlighted by Pedigo et al (1986) who suggested that injuries from different pests which produce the same host response can be grouped into injury guilds (Peterson 2001), and therefore, EILs for multiple pests could be developed.

Hutchins et al (1988) developed a technique that grouped insects by injury based on the plant physiological response to this damage. The investigators defined injury in standard units termed "injury equivalents." An insect-injury equivalent would be the total injury produced by a single pest over its lifespan. Thus, insect-injury equivalents have been proposed for making management decisions as part of a pest guide,

Table 2 Soybean yield (mean $\pm \mathrm{SE}$; in kilograms per hectare) obtained in experiments conducted under different pest management systems, within five different municipalities in two soybean-producing Brazilian states [Goiás (GO) and Paraná (PR)], during the 2008/2009 and 2009/2010 crop seasons.

\begin{tabular}{|c|c|c|c|c|c|}
\hline \multirow[t]{2}{*}{ Treatment } & \multicolumn{3}{|c|}{$2008 / 2009$ crop season $^{a}$} & \multicolumn{2}{|c|}{$2009 / 2010$ crop season $^{a}$} \\
\hline & $\begin{array}{l}\text { Castelândia, } \\
\text { GO }\end{array}$ & $\begin{array}{l}\text { Santa Helena } \\
\text { de Goiás, GO }\end{array}$ & $\begin{array}{l}\text { Senador } \\
\text { Canedo, GO }\end{array}$ & $\begin{array}{l}\text { Morrinhos, } \\
\text { PR }\end{array}$ & $\begin{array}{l}\text { Arapongas, } \\
\text { PR }\end{array}$ \\
\hline IPM & $3,180.40 \pm 185.43 a$ & $2,447.01 \pm 178.60^{\mathrm{ns}}$ & $2,913.56 \pm 200.37^{\mathrm{ns}}$ & $4,179.25 \pm 128.64^{n s}$ & $2,992.57 \pm 65.86 \mathrm{a}$ \\
\hline $\begin{array}{l}\text { Conventional Management (CM; use } \\
\text { of insecticides mixed with } \\
\text { herbicides and fungicides) }\end{array}$ & $2,981.49 \pm 178.97 \mathrm{a}$ & $2,441.33 \pm 208.19$ & $2,832.85 \pm 277.65$ & $3,902.50 \pm 84.18$ & $3,175.72 \pm 51.49 a$ \\
\hline Control (C) & $2,555.12 \pm 73.14 \mathrm{~b}$ & $2,228.62 \pm 166.52$ & $2,487.32 \pm 71.71$ & $3,797.50 \pm 96.81$ & $2,667.83 \pm 89.42 b$ \\
\hline CV (\%) & 5.54 & 4.54 & 13.86 & 5.79 & 3.84 \\
\hline
\end{tabular}

Adapted from Bueno et al (2011a).

IPM integrated pest management, $C M$ conventional management usually adopted by Brazilian soybean growers with overuse of insecticides, $C$ control treatment: without pest control, ns nonsignificant.

${ }^{a}$ Means followed by the same letter in the column are not significantly different between each other by the Tukey's test $(P>0.05)$. 
such as a complex of defoliators. Using this method, Hutchins et al (1988) grouped five defoliators and developed an EIL based on their insect-injury equivalent.

As in the work developed by Hutchins et al (1988), Bueno et al (2011b) proposed an insect-injury equivalent for five different caterpillars commonly found in Brazilian soybean fields. By accounting for its consumption, $A$. gemmatalis was set as the standard equivalent species, and the Spodoptera cosmioides (Walker) insect-injury equivalent was significantly different from the others species insect-injury equivalents and was nearly double that of $A$. gemmatalis (Table 3 ). This species was used to calculate the ET presently in use for 20 lepidopteran larvae per row meter. The authors concluded that the injury equivalent should be two for $S$. cosmioides and one for all other tested species ( $C$. includes, Spodoptera eridania (Cramer), Spodoptera frugiperda (Smith), and A. gemmatalis). Therefore, the recommended ET for triggering insect control would be 20 insect equivalents per sample-cloth (1-m-soybean line), similar to the level proposed for other soybean defoliators (Hutchins et al 1988, Haile et al 1998). However, it is important to emphasize that this injury equivalency system can sometimes be erratic because if insect densities are high, competition can reduce injury rates per individual. This issue should be examined in future ET studies for soybean pests, focusing on the necessary changes in injury equivalency. This result might be achieved by an appropriate adjustment based on the density-injury per individual function, which could be easily developed as part of an interactive computer implementation of the multiple-species ET model (Hammond et al 1979), and will certainly be a great improvement for future ET recommendations in Soybean-IPM.

Table 3 Insect-injury equivalent calculated for five species of lepidopteran larvae feeding on four soybean cultivars.

\begin{tabular}{lllll}
\hline Pest species & \multicolumn{2}{l}{ Soybean genotypes } & & \\
\cline { 2 - 5 } & Codetec 219RR & MSoy 6101 & MSoy 8787RR & Conquista \\
\hline $\begin{array}{l}\text { Anticarsia } \\
\text { gemmatalis }\end{array}$ & $1.00 \pm 0.05 \mathrm{bA}$ & $1.00 \pm 0.06 \mathrm{bA}$ & $1.00 \pm 0.07 \mathrm{bA}$ & $1.00 \pm 0.04 \mathrm{bA}$ \\
$\begin{array}{l}\text { Chrysodeixis } \\
\text { includens }\end{array}$ & $1.00 \pm 0.05 \mathrm{bA}$ & $0.86 \pm 0.10 \mathrm{bA}$ & $0.86 \pm 0.11 \mathrm{bA}$ & $0.71 \pm 0.05 \mathrm{bA}$ \\
$\begin{array}{l}\text { Spodoptera } \\
\text { cosmioides }\end{array}$ & $1.98 \pm 0.16 \mathrm{aB}$ & $2.49 \pm 0.12 \mathrm{aA}$ & $1.95 \pm 0.06 \mathrm{aB}$ & $1.94 \pm 0.06 \mathrm{aB}$ \\
$\begin{array}{l}\text { Spodoptera } \\
\text { eridania }\end{array}$ & $1.16 \pm 0.07 \mathrm{bA}$ & $1.32 \pm 0.15 \mathrm{bA}$ & $1.07 \pm 0.05 \mathrm{bA}$ & $0.97 \pm 0.08 \mathrm{bA}$ \\
$\begin{array}{l}\text { Spodoptera } \\
\text { frugiperda } \\
\text { CV (\%) }\end{array}$ & $1.27 \pm 0.07 \mathrm{bA}$ & $1.21 \pm 0.13 \mathrm{bA}$ & $1.21 \pm 0.06 \mathrm{bA}$ & $1.06 \pm 0.09 \mathrm{bA}$ \\
& 10.6 & & & \\
\hline
\end{tabular}

Means followed by similar uppercase letters in a row or by lowercase letters in a column are not significantly different according to Tukey's studentized range test at $5 \%$ probability. Original data, followed by statistics performed on data transformed to $\sqrt{X}$. Adapted from Bueno et al (2011b).
Finally, the incorporation of mortality factors or pest survival information in ET (Ostile \& Pedigo 1987, Barrigossi et al 2003, Paula-Moraes et al 2013) represents an improvement in ET development. Pest mortality may be variable in different areas under which the soybean crop is cultivated. It may be possible to incorporate pest survival when establishing dynamic ETs (Paula-Moraes et al 2013), which can also be expressed in a pest stage different from that for which the EIL was defined.

\section{Concluding remarks}

To maintain the sustainability of global soybean production in the medium and long terms, an alternative to the overuse of insecticides is needed. The best technology available to date is soybean-integrated pest management (SoybeanIPM), which proposes the rational use of insecticides by adopting ETs to apply these chemicals only when necessary, as well as the harmonious integration of different control strategies in addition to chemicals (Zalucki et al 2009). In the IPM approach, the natural biological control of pests is always prioritized according to other auxiliary tactics, including the use of selective pesticides, which are only recommended as complementary resources. Pesticides are harmoniously applied to avoid damaging biological control. In this context, the adoption of ETs helps to increase natural biological control because fewer chemicals are applied to the environment.

The soybean crop in Brazil provides an example of how the adoption of ETs and IPM can be a tool to mitigate the negative impact of pesticides in agriculture. Prior to the adoption of Soybean-IPM by Brazil at the beginning of the 1970s, when insecticides were applied on a calendar basis, an average of six broad-spectrum insecticide applications were made per crop season. Following widespread adoption of Soybean-IPM, insecticides were used more appropriately, with growers considering the ETs for pest control. As a result, the use of insecticides was reduced to approximately two applications per crop season (Batistela et al 2012). At present, the Soybean-IPM technology has unfortunately been abandoned by the majority of Brazilian soybean growers, causing the number of insecticide applications to increase again. Therefore, a return to using ET for triggering insecticide applications is the best way to reduce the overuse of chemicals in soybeans without reducing crop yield and overall production, thus improving soybean crop sustainability.

Acknowledgments The authors would like Rudiney Ringenberg and Adônis Moreira for suggestions and previous manuscript corrections. The authors would also like to thank Embrapa Soja, CAPES, CNPq and FAPESP for their financial support and scholarships. This paper was approved for publication by the Editorial Board of Embrapa Soja as manuscript number 24/2013. 


\section{References}

Andrews G, Daves C, Koger T, Reed J, Burdine B, Dodds D, Larson E, Robbsins J, Catchot A, Gore J, Musser F, Smith J, Cook D, Jackson R, Mckibben $P$, Winters $S$ (2009)Insect control guides for cotton, soybeans, corn, grain sorghum, wheat, sweet potatoes \& pastures. \{S.I.\}: Mississippi State University Extension Service, $64 \mathrm{p}$

Barrigossi JAF, Hein GL, Higley LG (2003) Economic injury levels and sequential sampling plans for Mexican bean beetle (Coleoptera: Coccinellidae) on dry beans. J Econ Entomol 96:1160-1167

Batistela MJ, Bueno AF, Nishikawa MAN, Bueno RCOF, Hidalgo G, Silva L, Corbo E, Silva RB (2012) Reevaluation of leaf-lamina consumer thresholds for IPM decisions in short-season soybeans using artificial defoliation. Crop Prot 32:7-11

Board JE, Kumudini S, Omielan J, Prior E, Kahlon CS (2010) Yield response of soybean to partial and total defoliation during the seed-filling period. Crop Sci 50:703-712

Brougham RW (1956) Effect of intensity of defoliation on regrowth of pasture. Aust JAgric Res 7:377-387

Brougham RW (1958) Interception of light by the foliage of pure and mixed stands of pasture plants. Aust J Agric Res 9:39-52

Bueno AF, Batistela MJ, Bueno RCOF, França-Neto JB, Nishikawa MAN, Filho AL (2011a) Effects of integrated pest management, biological control and prophylactic use of insecticides on the management and sustainability of soybean. Crop Prot 30:937-945

Bueno AF, Panizzi AR, Corrêa-Ferreira BS, Hoffmann-Campo CB, SosaGómez DR, Gazzoni DL, Hirose E, Moscadi F, Corso IC, Oliveira LJ, Roggia S (2012) Histórico e evolução do manejo integrado de pragas da soja no Brasil. In: Hoffmann-Campo CB, Moscadi F, Corrêa-Ferreira BS (eds) Soja: manejo integrado de insetos e outros artrópodes-praga. Embrapa, Brasília, $859 \mathrm{p}$

Bueno RCOF, Bueno AF, Moscardi F, Parra JRP, Hoffmann-Campo CB (2011b) Lepidopteran larvae consumption of soybean foliage: basis for developing multiple-species economic thresholds for pest management decisions. Pest Manag Sci 67:170-174

Carson RL (1962) Silent spring. Houghton Mifflin, Boston, 368 p

Companhia Nacional de Abastecimento (CONAB) (2013) Brazilian harvest monitoring - grain crop 2012/2013. Brasília, 32 p. Available at: <http://www.conab.gov.br/OlalaCMS/uploads/arquivos/13_08_16_ 16_25_02_boletim_ingles_agosto_2013.pdf>. Accessed 3 June 2013

Corrêa-Ferreira BS, Alexandre TM, Pellizzaro EC, Moscardi F, Bueno AF (2010) Práticas de manejo de pragas utilizadas na soja e seu impacto sobre a cultura. Circular Técnica, 78. Embrapa Soja, Londrina, $15 \mathrm{p}$

Costa MAG, Balardin RS, Costa EC, Grützmacher AD, Silva MTB (2003) Níveis de desfolha na fase reprodutiva da soja, cv. Ocepar 14, sobredoissistemas de cultivo. Ciênc Rural 33:813-819

Davidson JL, Donald CM (1958) The growth of swards of subterranean clover with particular reference to leaf area. Aust J Agric Res 9:5372

Gazzoni DL, Moscardi F (1998) Effect of defoliation levels on recovery of leaf area, on yield and agronomic traits of soybeans. Pesqui Agropecu Bras 33:411-424

Geier PW, Clark LR (1961) An ecological approach to pest control. In: Proc. Tech. Meeting Intern. Unio Conser. Nature and Nat. Resources, 8th, 1960, Warsaw, Poland, pp 10-18

Haile FJ, Higley LG, Specht JE (1998a) Soybean cultivars and insect defoliation: yield loss and economic injury levels. Agron J90:344352

Haile FJ, Higley LG, Specht JE, Spomer SM (1998b) Soybean leaf morphology and defoliation tolerance. Agron J 90:353-362

Hammond RB (1996) Limitations to EIL and thresholds. In: Higley LG, Pedigo LP (eds) Economic thresholds for integrated pest management. University of Nebraska Press, pp 58-73

Hammond RB, Pedigo LP, Poston FL (1979) Green cloverworm leaf consumption on greenhouse and field soybean leaves and development of a leaf consumption model. J Econ Entomol 72: 714-717

Higley LG, Pedigo LP (1996) The EIL concept. In: Higley LG, Pedigo LP (eds) Economic threshold for integrated pest management. University of Nebraska press, Lincoln and London, $327 \mathrm{p}$

Higley LG, Peterson RKD (1996) The biological basis of the EIL. In: Higley LG, Pedigo LP (eds) Economic threshold for integrated pest management. University of Nebraska press, Lincoln and London, $327 \mathrm{p}$

Hutchins SH, Higley LG, Pedigo LP (1988) Injury equivalency as a basis for developing multiple-species economic injury levels. J Econ Entomol 81:1-8

Kogan M (1998) Integrated pest management: historical perspectives and contemporary developments. Annu Rev Entomol 43:243-270

Kumudini S, Hume DJ, Chu G (2001) Genetic improvement in shortseason soybeans: I. Dry matter accumulation, partitioning, and leaf area duration. Crop Sci 41:391-398

Meissle M, Mouron P, Musa T, Bigler F, Pons X, Vasileiadis VP, Otto S, Antichi D, Kiss J, Pálinkás Z, Dorner Z, Van Der Weide R, Groten J, Czembor E, Adamczyk J, Thibord J-B, Melander B, Cordsen-Nielsen G, Poulsen RT, Zimmermann O, Vershwele A, Oldenburg E (2010) Pest, pesticides use and alternative options in European maize production: current status and future prospects. J Appl Entomol 134:357-375

Murata Y (1961) Studies on photosynthesis in rice plants and its culture significance. Bul Natl Inst Agric Sci 1-25

Naranjo SE, Ruberson JR, Sharma HC, Wilson L, Wu K (2008) The present and future role of insect-resistant genetically modified cotton in IPM. In: Romeis J, Shelton AM, Kennedy GG (eds) Integration of insectresistant genetically modified crops within IPM programs. Springer, The Netherlands, pp 159-194

Ostlie KR, Pedigo LP (1987) Incorporating pest survivorship into economic thresholds. Bull Entomol Soc Am 33:98-102

Panizzi AR, McPherson JE, James DG, Javahery $M$, McPherson RM (2000) Economic importance of stink bugs (Pentatomidae). In: Schaefer CW, Panizzi AR (eds) Heteroptera of economic importance. CRC, Boca Raton, pp 421-474

Panizzi AR (2013) History and contemporary perspectives of the integrated pest management of soybean in Brazil. Neotrop Entomol 42: 119-127

Paula-Moraes SV, Hunt TE, Wright RJ, Hein GL, Blankenship EE (2013) Western bean cutworm survival and the development of economic injury levels and economic thresholds in field corn. J Econ Entomol 106:1274-1285

Paula SV, Picanço MC, Fontes PCR, Vilela EF (1998) Fatores de Perdas no Tomateiro com Adoção de Nível de Controle e Faixas Circundantes. Agrociencia (Montecillo) 14:263-271

Pedigo LP (1995) Closing the gap between IPM theory and practice. J Agric Entomol 12:171-181

Pedigo LP, Higley LG (1996) Introduction to pest management and thresholds. In: Higley LG, Pedigo LP (eds) Economic threshold for integrated pest management. University of Nebraska press, Lincoln and London, $327 \mathrm{p}$

Pedigo LP, Rice ME (2009) Entomology and pest management, 6th ed. Prentice Hall, Upper Saddle River, New Jersey, xxvii $+749 p$

Pedigo LP, Hutchins SH, Higley LG (1986) Economic injury levels in theory and practice. Annu Rev Entomol 31:341-368

Peterson RKD (2001) Photosynthesis, yield loss, and injury guilds. In: Peterson RKD, Higley LG (eds) Biotic stress and yield loss. CRC, Boca Raton, pp 83-96

Peterson RKD, Higley LG (2001) Illuminating the black box: the relationship between injury and yield. In: Peterson RKD, Higley LG (eds) Biotic stress and yield loss. CRC, Boca Raton. $261 \mathrm{p}$

Picanço MC, Paula SV, Moraes Junior AR, Oliveira IR, Semeão AA, Rosado JF (2004) Impactos financeiros da adoção de manejo integrado de pragas na cultura do tomateiro. Acta Sci Agron $26: 245-252$ 
Pickle CS, Caviness CE (1984) Yield reduction from defoliation and plant cutoff of determinate and semideterminate soybean. Agron J 76:474-476

Reichert JL, Costa EC (2003) Desfolhamentos contínuos e seqüenciais simulando danos de pragas sobre o cultivar de soja BRS 137. Ciênc Rur 33:1-6

Stern VM, Smith RF, Van Den Bosch R, Hagen KS (1959) The integrated control concept. Hilgardia 29:81-101

Stern WR, Donald CM (1962) The influence of leaf area and radiation on the growth of clover in swards. Aust J Agric Res 13:615-623
Tang S, Tang G, Cheke RA (2010) Optimum timing for integrated pest management: modeling rates of pesticides application and natural enemy releases. J Theor Biol 264:623-638

Turnipseed SG (1972) Response of soybeans to foliage losses in South Carolina. J Econ Entomol 65:224-229

Watson DJ (1958) The dependence of net assimilation rate on leaf area index. Ann Bot 22:37-54

Zalucki MP, Adamson D, Furlong MJ (2009) The future of IPM: whither or wither? Aust J Entomol 48:85-96 